九州大学学術情報リポジトリ

Kyushu University Institutional Repository

Nine new species of the genus Pachyrhynchus Germar (Coleoptera: Curculionidae) from the Philippines

Yoshitake, Hiraku

Natural Resources Inventory Center, National Institute for Agro-Environmental Sciences

https://doi.org/10.5109/25392

出版情報: ESAKIA. 52，pp.17-34，2012-03-27. Entomological Laboratory，Faculty of Agriculture， Kyushu University

バージョン :

権利関係 : 


\title{
Nine New Species of the Genus Pachyrhynchus Germar (Coleoptera: Curculionidae) from the Philippines
}

\author{
Hiraku Yoshitake \\ Natural Resources Inventory Center, National Institute for Agro-Environmental Sciences, \\ 3-1-3 Kannondai, Tsukuba, 305-8604, Japan
}

\begin{abstract}
Nine new species of the genus Pachyrhynchus Germar are described from the Mindanao Islands, the Philippines: P. caeruleovittatus sp. nov., P. hirokii sp. nov., P. naokii sp. nov., P. pseudamabilis sp. nov., $P$. subamabilis sp. nov., $P$. tadauchii sp. nov. and $P$. zamboanganus sp. nov. from Mindanao Island, and P. sphenomorphoides sp. nov. from Basilan Island. The diagnosis of each species is provided. Habitus photographs and illustrations of male and/or female genitalia for these new species are also included.
\end{abstract}

Key words: taxonomy, Pachyrhynchini, new species, Mindanao, Basilan.

\section{Introduction}

The genus Pachyrhynchus Germar, 1824, in the tribe Pachyrhynchini, subfamily Entiminae (Alonso-Zarazaga \& Lyal, 1999), is characterized mainly by the head lacking a distinct transverse groove between forehead and rostrum, dorsally swollen rostrum on apical half, simple antennal scrobes, antennal scape not reaching posterior margin of eye, and entire episternal suture (Schultze, 1923). Presently, this genus comprises 96 species mostly from the Philippines (Dalla Torre \& Emden, 1931; Schultze, 1934; Schultze, 1937; Marshall, 1952; Kuschel, 2008). As Schultze (1923) suggested, however, a large number of undescribed species of Pachyrhynchus occur in the Philippines.

In the course of my taxonomic and inventory research of the Pachyrhynchini from the viewpoint of plant quarantine, I had an opportunity to examine specimens of nine undetermined Pachyrhynchus species from the Mindanao Islands, Philippines. After careful examination including male and female genitalia, I concluded that all of them are new to science. In this paper, I am going to describe them as new species to improve our knowledge of this genus.

It is my great pleasure to be able to dedicate this small paper to Prof. Osamu Tadauchi on the commemorative occasion of his retirement from Kyushu University in
March, 2012.

\section{Materials and methods}

This study was based on specimens deposited at the National Institute for Agro-Environmental Sciences, Tsukuba (NIAES), Museum für Tierkunde, Dresden (MTD), and private collection of Kaoru Sakai, Tokyo (PCKS). The methods used in this study were the same as those explained in Yoshitake (2011). The holotypes of the new species described herein are preserved in NIAES.

\section{Taxonomy}

Pachyrhynchus tadauchii sp. nov.

(Figs. 1, 2, 17-23)

Diagnosis. Pachyrhynchus tadauchii is similar in general appearance to $P$. davaoensis Schultze, 1934, which was described based only on the male holotype collected from Mt. Apo, Mindanao Island. However, $P$. tadauchii is easily distinguishable from $P$. davaoensis by the unique scaly markings on the prothorax and elytra and the wider prothorax and apices of the elytra at least in the male.

Description. Male. Dimensions: LB: 9.60-11.65 

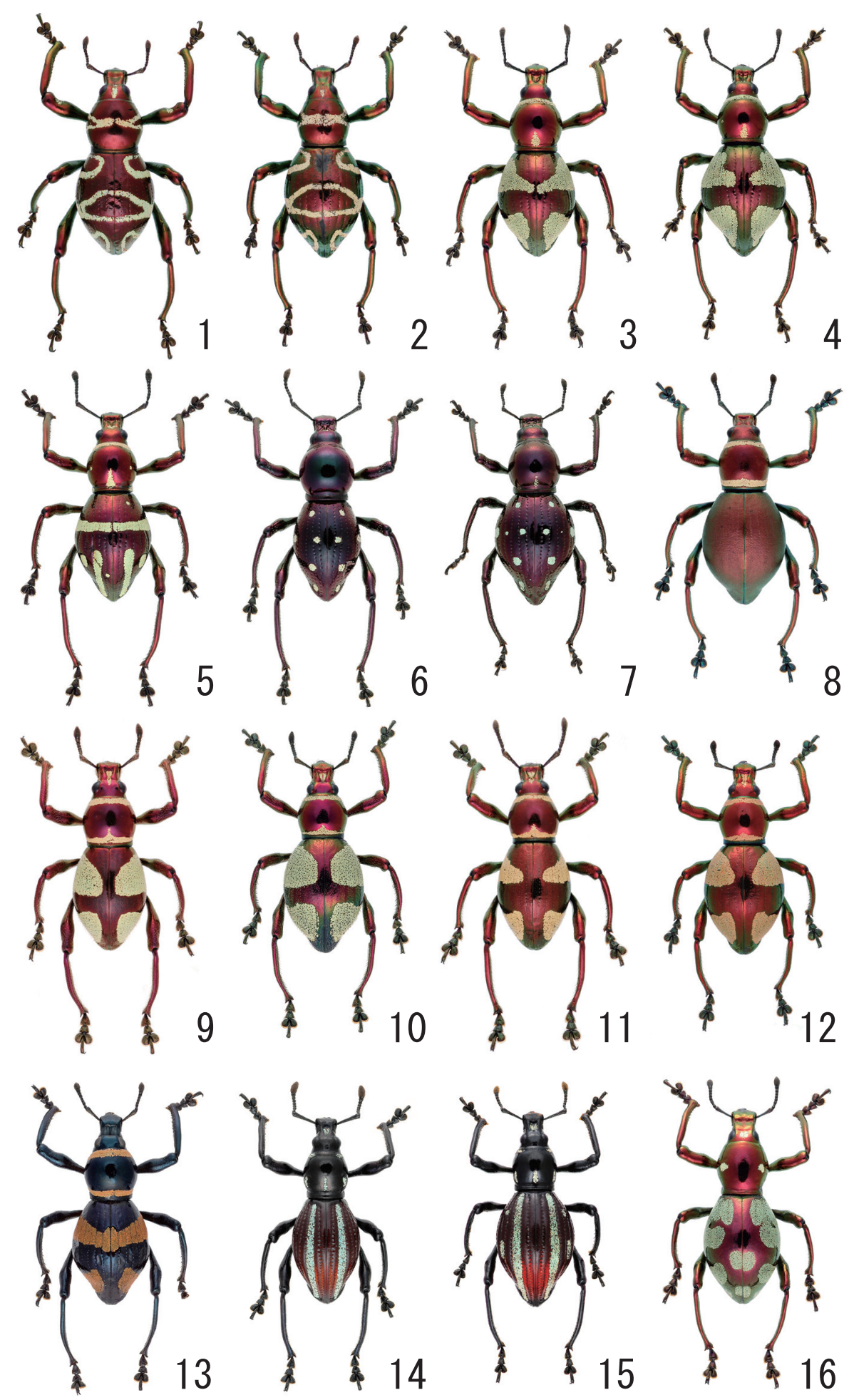

Figs. 1-16. Dorsal habitus of Pachyrhynchus spp. - 1, Pachyrhynchus tadauchii sp. nov., holotype male; 2 , ditto, paratype female; 3 , $P$. hirokii sp. nov., holotype male; 4, ditto, paratype female; 5, P. naokii sp. nov., holotype male; 6, P. sphenomorphoides sp. nov., holotype male; 7, ditto, paratype female; 8 , P. subamabilis sp. nov., holotype female; 9, P. pseudamabilis sp. nov., holotype male; 10 , ditto, paratype female; 11 , ditto, paratype male; 12, ditto, paratype female; 13, P. zamboanganus sp. nov., holotype female; 14, P. caeruleovittatus sp. nov., holotype male; 15 , ditto, paratype female; 16, P. apoensis sp. nov., holotype male. 
(holotype 9.60; mean 11.11). LR: 1.50-1.75 (holotype 1.50; mean 1.68). WR: 1.50-1.70 (holotype 1.50; mean 1.64). LP: 3.30-3.85 (holotype 3.30; mean 3.66). WP: 3.45-4.25 (holotype 3.45; mean 3.98). LE: 6.55-8.05 (holotype 6.55; mean 7.56). WE: 4.80-5.70 (holotype 4.80; mean 5.45). $\mathrm{N}=5$ for all measurements. Dorsal habitus as shown in Fig. 1.

Integument wine red, sometimes with green tinge; antennae reddish black except black scapes; tarsi coppery black. Body surface mostly strongly shiny except underside with weaker luster.

Body mostly subglabrous, with glossy pale green markings of recumbent round to elliptic scales. Head sparsely very minutely pubescent, with narrow elliptic scaly patch along midline; scaly patch extending from vertex to apex of forehead. Rostrum sparsely very minutely pubescent on dorsum; lateroventral parts except antennal scrobes densely covered with general scales, mingled with linear to hair-like scales, and furnished with long golden hairs near apex. Prothorax dorsally with transverse scaly band in middle, sometimes with scaly stripe on basal half along midline; scaly band laterally bifid in dorsal view, forming distorted ovate ring marking on each side in lateral view. Each elytron sparsely minutely pubescent on apical $1 / 3$, with the following three scaly markings: 1) distorted ovate ring marking on basal $1 / 3$, which extends transversely from interval II to lateral margin, 2) two transverse median bands on entire width, which are well-separated on suture, then approximated laterally, and finally broadly connected on side, and 3) distorted subtriangular ring marking on apical $1 / 3$, which extends from interval II to lateral margin; median and apical markings often connected laterally by marginal stripe. Anterior parts of fore coxae covered with general scales, mingled with short light-colored hairs. Fore femora rather densely covered with short hairs and linear to elliptic scales near base along anterior margins, each with scaly patch on subapical part exept posterior half. Mid and hind femora thinly covered with short hairs and hair-like scales along posterior margins, each with scaly patch on subapical part except anterior half. Tibiae sparsely minutely pubescent, mingled with long hairs; each tibia fringed with long hairs along internal margin, sparsely mingled with stout hairs; vestiture slightly denser on apical parts. Prosternum mostly densely covered with general scales. Intercoxal part of mesosternum entirely densely covered with general scales. Metasternum mostly covered with general scales, which become denser on sides. Venter sparsely minutely pubescent; ventrite I with a pair of large scaly patches on sides along apical margin; ventrite II with a pair of larger scaly patches on sides along apical margin; ventrites III and IV furnished with long hairs along apical margins, sometimes with some scattered scales; ventrite $\mathrm{V}$ covered with longer suberect hairs on apical $1 / 3$.

Head moderately minutely punctured; forehead slightly depressed along midline, nearly twice as wide as eye width; eyes relatively large, moderately prominent from outline of head. Antennae with scape short and stout, slightly shorter than funicle, strongly clavate; funicle relatively stout; funicular segment I nearly twice as long as wide, slightly longer than II; segment II 1.5 times as long as wide, 1.5 times as long as III; segments III-V subequal in length and width, slightly wider than long, slightly shorter and narrower than VI; segment VI slightly wider than long, slightly shorter and narrower than VII; segment VII slightly wider than long; club subellipsoidal, nearly twice as long as wide, as long as funicular segments IV to VII combined. Rostrum nearly as long as wide, LR/WR 1.00-1.06; dorsum moderately minutely punctured, with shallow obovate concavity on basal half, weakly bulging on apical half; apical bulge flattish dorsally, but faintly depressed in middle of basal half; dorsal contour of forehead and rostrum subcontinuous; dorsal contour of rostrum flattish in basal half, then gradually raised at basal half, and finally gradually declined to apex; sides moderately widened apically; ventral surface simple. Prothorax subspherical, nearly as long as or slightly longer than wide, WP/LP 1.05-1.12; dorsum faintly minutely punctured, slightly depressed on scaly part, flattish on disc; dorsal contour highest at basal $1 / 3$; sides rather strongly dilated from rather strongly constricted base, widest at middle, then rather strongly convergent apicad, and finally narrowly faintly constricted just behind apex; basal margin subtruncate; apical margin shallowly arched; subbasal groove entirely distinct; subapical groove obscure. Elytra broadly subobovate, LE/ WE 1.36-1.42, moderately convex dorsally, wider than prothorax, WE/WP 1.33-1.40, nearly twice as long as prothorax, LE/LP 1.99-2.13, moderately striate-punctured, with intervals evenly flattish; dorsal contour highest at apical 1/3; sides gradually dilated from base, widest just before middle, then rather strongly narrowed to faint subapical constrictions, and finally gently rounded at apices. Legs stout; femora rather strongly clavate; tibiae serrate along internal margins, strongly incurved apically, mucronate at apices; tibial mucrones well-developed on all legs. Metasternum and ventrite I widely conjointly depressed on disc, forming large circular depression; apex of discal depression not reaching apical margin of ventrite I. Ventrite V widely subtruncate at apex. Genitalia as illustrated (Figs. 17-20). Spiculum gastrale (Fig. 19) 
relatively stout, slightly longer than aedeagal body, strongly curved leftward. Tegmen (Fig. 20) with slender apodeme which is nearly 1.5 times as long as diameter of tegminal ring. Aedeagal body (Figs. 17, 18) stout, strongly curved ventrally near base, widely produced in long lamina at apex; sides slightly constricted in subbasal part, subparallel to basal 3/4, rather strongly narrowed to subapical constriction, then subparallel to before apex, and finally acutely rounded at apex; aedeagal apodemes slender, near as long as aedeagal body. Endophallus (Fig. 17) bearing short flagellum guide in basal part and laminate sclerite in subbasal part; laminate sclerite gradually widened from base to apical $1 / 3$, then deeply trifid apically, and finally connected with obreniform sclerite at apex of longest median lobe.

Female. Dimensions: LB: 11.5. LR: 2.7. WR: 2.65. LP: 3.45. WP: 3.8. LE: 8.3. WE: 5.7. Dorsal habitus as shown in Fig. 2.

Rostrum LR/WR 1.02. Prothorax WP/LP 1.10. Elytra slightly wider, LE/WE 1.46, much wider than prothorax, WE/WP 1.50, more strongly elongate apically, LE/LP 2.41, and acutely rounded at apices. Metasternum simple, not depressed on disc. Venterite I slightly inflated. Ventrite $\mathrm{V}$ widely shallowly depressed along lateral margins, shallowly emarginate in middle of apical margin which is narrowly subtruncate. Genitalia as illustrated (Figs. 21-23). Otherwise, essentially as in males.

Type material. Holotype male (NIAES Type Specimen Code No. COL-274), "[REP. OF THE PHILIPPINES] / Northeast Mindanao, Surigao / del Sur Prov., Bislig, IX. 2010" (typed on a white card), "HIRAKU YOSHITAKE / COLLECTION" (typed on a white card), "[HOLOTYPE] Male / Pachyrhynchus tadauchii / Yoshitake, 2012 / Det. Hiraku Yoshitake, 2011" (typed on a red card). Paratypes (5 exs.). PHILIPPINES: MINDANAO ISLAND. Bislig, Surigao del Sur Province: 1 male, ix. 2010, native collector leg. (Specimen No. 24-0474257, NIAES); 1 female, xi. 2010, native collector leg. (Specimen No. 24-0474258, NIAES); 1 male, iv. 2011, native collector leg. (Specimen No. 24-0474259, NIAES); 1 male, vi. 2011, native collector leg. (Specimen No. 24-0474260, NIAES); 1 male, vii. 2011, native collector leg. (Specimen No. 24-0474261, NIAES).

Distribution. Philippines: Mindanao Island (Surigao der Sur Province).

Etymology. The new species is named in honor of Prof. Osamu Tadauchi (Kyushu University), who is a keen specialist on hymenopteran insects. He has endeavored for many years to construct essential databases of Asian insects.

\section{Pachyrhynchus hirokii sp. nov.}

(Figs. 3, 4, 24-30)

Pachyrhynchus venustus: Sakaguti, 1979 (nec Waterhouse, 1841), 90, pl. 23, fig. 6 (Japanese name: Akagane-katazou; Mt. Apo, Mindanao).

Diagnosis. Pachyrhynchus hirokii is similar in general appearance to $P$. semiignitus Schultze, 1922, which was described based only on the holotype male collected from Cotabato Province, Mindanao Island. However, P. hirokii clearly differs from $P$. semiignitus by the wider and more convex prothorax and the narrower elytra with a strong luster and the unique scaly markings in the male.

Description. Male. Dimensions: LB: 8.30-10.00 (holotype 9.70; mean 9.45). LR: 1.40-1.60 (holotype 1.60; mean 1.53). WR: 1.30-1.55 (holotype 1.50; mean 1.45). LP: 2.70-3.40 (holotype 3.30; mean 3.18). WP: 2.85-3.40 (holotype 3.30; mean 3.20). LE: 5.70-6.60 (holotype 6.60; mean 6.34). WE: 4.40-5.60 (holotype 4.80; mean 4.92). $\mathrm{N}=5$ for all measurements. Dorsal habitus as shown in Fig. 3.

Integument dark glowing red; antennae and tarsi darker. Body surface mostly strongly shiny, except underside with weaker luster.

Body moderately minutely pubescent on most parts, with glossy pale green markings of round recumbent scales. Forehead with small scaly spot in middle of apex. Each side of rostrum densely covered with general scales and short hair-like scales on lateroventral part behind antennal scrobe, and covered with pale green linear scales and golden long hair-like scales on lateral part before it. Prothorax with the following four scaly markings: 1) longitudinal median patch near base, 2) broad lateroventral stripe on each side, 3) a pair of transverse lateral patches along basal margin, and 4) transverse band along apical margin; paired patches very widely separated; pronotum sometimes with a pair of small lateral spots of some general scales in middle. Each elytron with two large subtriangular scaly patches, one on basal half and another on apical half; basal patch with basal margin angulate on interval III, extending from suture to external margin, but often diminished on interval I, then gradually widened externally to interval III, and finally rapidly expanded toward external margin; apical patch with basal margin arched posteriorly, with internal margin deeply narrowly emarginate on interval IX, extending from interval II to external margin. Anterior parts of fore coxae covered with general scales, mingled with light-colored hairs. Fore femora rather densely covered with fine hairs and light-colored elliptic to hair-like scales along anterior 

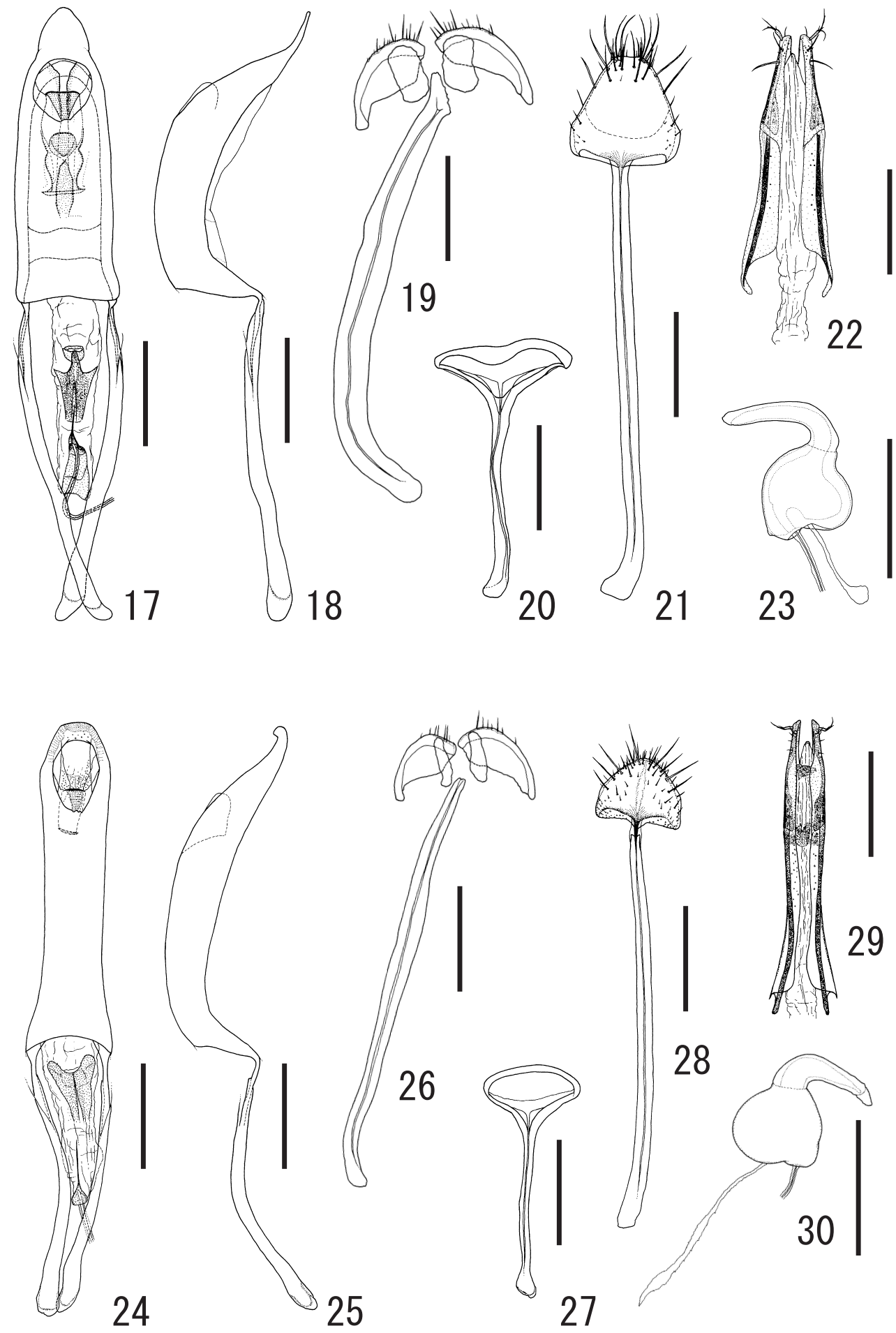

Figs. 17-30. Male and female genitalia of Pachyrhynchus spp. - 17-20, Pachyrhynchus tadauchii sp. nov., holotype male; 21-23, ditto, paratype female; 24-27, Pachyrhynchus hirokii sp. nov., holotype male; 28-30, ditto, paratype female. 17, 24, Aedeagus in dorsal view; 18, 25, aedeagus in lateral view; 19, 26 , sternite IX in dorsal view; 20, 27, tegmen in dorsal view. 21, 28, sternite VIII in ventral view; 22, 29 , apex of ovipositor in dorsal view; 23,30 , spermatheca. Scale: $0.50 \mathrm{~mm}$. 
margins; scales become sparse and minute medially. Mid and hind femora covered with similar scales to those on fore pair on basal parts of dorsal surfaces and along posterior margins. Tibiae fringed with long hairs along internal margins, sparsely mingled with stout hairs; fore tibiae sparsely covered with long light-colored hairs and hairlike scales, except dorsal surfaces minutely pubescent; vestiture denser along internal margins and on apical parts; mid and hind tibiae mostly covered with similar scales to those on fore pair, but subglabrous on ventral surfaces. Prosternum mostly covered with dense general scales; intercoxal part of mesosternum entirely densely covered with general scales; metasternum mostly covered with general scales, which become denser on sides; ventrite I sparsely covered with fine light-colored hairs, with a pair of large lateral patches of general scales along apical margin; ventrite II with a pair of small lateral patches of general scales along apical margin, sparsely furnished with hairs in patches; ventrite V laterally furnished with several erect hairs along apical margin.

Head moderately minutely punctured; forehead flattish, nearly three times as wide as eye width; eyes relatively small, moderately convex from outline of head. Antennae with scape slender, nearly as long as funicle, moderately clavate; funicular segment I nearly 2.5 times as long as wide, slightly longer than II; segment II nearly twice as long as wide, nearly as long as III; segments IIIVI subequal in length, nearly as long as wide, slightly shorter than VII; segment VII nearly as long as wide; club subobovoid, nearly twice as long as wide. Rostrum nearly as long as wide, LR/WR 1.03-1.08; dorsum moderately minutely punctured, with deep obovate concavity on basal half, strongly bulging on apical half; apical bulge dorsally flattish, with shallow median sulcus; dorsal contour of forehead and rostrum slightly discontinuous; dorsal contour of rostrum weakly arched in basal half, abruptly raised at basal half, then gradually declined to apex; sides slightly widened apically; ventral surface simple, not convex along midline. Prothorax subglobular, slightly nearly as long as wide, WP/LP 0.99-1.06; dorsum smooth, faintly minutely punctured, moderately convex; dorsal contour highest at apical 1/3; sides rather strongly dilated from strongly constricted base, widest at middle, strongly convergent apicad, and then slightly narrowly constricted at apex; basal margin faintly widely emarginate in middle; apical margin shallowly arched; subbasal and subapical grooves entirely distinct. Elytra broadly subobovate, LE/ WE 1.11-1.38, much wider than prothorax, WE/WP 1.44-1.81, nearly twice as long as prothorax, LE/LP 1.942.11, moderately striate-punctured, with intervals evenly flattish; dorsum rather strongly convex; dorsal contour highest at middle; sides gradually dilated from base, widest just before middle, rather strongly narrowed to subapical constriction, and then slightly acutely rounded at apices. Metasternum and ventrite I widely conjointly depressed on disc, forming large circular depression; apex of discal depression reaching apical margin of ventrite I. Ventrite $\mathrm{V}$ shallowly emarginate in middle of apex. Legs slender; femora moderately clavate; tibiae weakly incurved apically, minutely serrate along internal margins; each tibia mucronate at apex; tibial mucrones vestigial on hind legs. Genitalia as illustrated (Figs. 24-27). Spiculum gastrale (Fig. 26) slender, slightly longer than aedeagal body, faintly curved leftward. Tegmen (Fig. 27) with very slender apodeme which is nearly twice as long as diameter of tegminal ring. Aedeagal body (Figs. 24, 25) slender, in lateral view, rather strongly curved ventrally near base, gradually attenuate apically from subapical part, and bent dorsally at apex; sides rather strongly narrowed from base to basal $1 / 5$, subparallel to basal $3 / 5$, then gradually expanded to subapical part, and finally strongly convergent to truncate apex; aedeagal apodemes nearly 0.7 times as long as aedeagal body. Endophallus (Fig. 24) bearing short flagellum guide in basal part and a pair of subspathulate laminate sclerites in subbasal part; laminate sclerites conjointly forming oblong-obcordate outline whose apical margin is deeply widely emarginate.

Female. Dimensions: LB: 9.40-10.80 (mean 10.12). LR: $1.40-1.60$ (mean 1.49). WR: 1.30-1.60 (mean 1.43). LP: $2.85-3.30$ (mean 3.04). WP: 2.90-3.50 (mean 3.21). LE: 6.60-7.70 (mean 7.18). WE: 5.00-5.90 (mean 5.5). N $=5$ for all measurements. Dorsal habitus as shown in Fig. 4.

Rostrum LR/WR 1.00-1.08. Prothorax WP/LP 1.021.11. Elytra much wider, LE/WE 1.27-1.34, WE/WP 1.69-1.74, more strongly elongate apically, LE/LP 2.282.50, more acute at apices. Metasternum simple, not depressed on disc. Venterites I and II slightly inflated. Ventrite $\mathrm{V}$ widely shallowly depressed along lateral margins, with obtuse triangular laminate projection in middle of apex. Genitalia as illustrated (Figs. 28-30). Otherwise, essentially as in males.

Type material. Holotype male (NIAES Type Specimen Code No. COL-275), “[REP. OF THE PHILIPPINES] / Mindanao I., Mt. Apo / IX. 2010, native collector” (typed on a white card), "HIRAKU YOSHITAKE / COLLECTION" (typed on a white card, "[HOLOTYPE] Male / Pachyrhynchus hirokii / Yoshitake, 2012 / Det. Hiraku Yoshitake, 2011" (typed on a red card). Paratypes (39 exs.). PHILIPPINES: MINDANAO ISLAND. Mt. Apo, North Cotabato Province: 2 males., iv. 2004, D. Mohagan leg. (PCKS); 1 male, iii. 2010, native collector 
leg. (Specimen No. 24-0474263, NIAES); 2 females, xii. 2010, native collector leg. (Specimen Nos. 24-0474295, 24-0474296). Mt. Apo: 1 male, v. 1987, native collector leg. (PCKS); 1 male, 5. v. 1987, native collector leg. (PCKS); 2 males and 1 female, iv. 2010, native collector leg. (Specimen Nos. 24-0474264 24-0474266, NIAES); 2 males and 3 females, v. 2010, native collector leg. (Specimen Nos. 24-0474267 24-0474271, NIAES); 6 males and 4 females, vi. 2010, native collector leg. (Specimen Nos. 24-0474272 24-0474281, NIAES); 3 males and 8 females, ix. 2010, native collector leg. (Specimen Nos. 24-0474282 24-0474292, NIAES); 2 males, xi. 2010, native collector leg. (Specimen Nos. 24-0474293, 24-0474294, NIAES); 1 female (Specimen No. 24-0474297, NIAES; with no further data).

Distribution. Philippines: Mindanao Island (Mt. Apo).

Etymology. The specific name is dedicated with my deepest love and gratitude to one of my twins, Hiroki, who always encourages me with a charming smile.

\section{Pachyrhynchus naokii sp. nov.} (Figs. 5, 38-41)

Diagnosis. Pachyrhynchus naokii is similar to $P$. hirokii in general appearance and male genital structures, but it can be distinguished from P. hirokii at a glance by the unique scaly markings on the elytra, more strongly convex eyes, more elongate elytra, and slenderer legs with darker vestiture (Fig. 5). In addition, the configurations of male aedeagal apex and endophallic sclerites are different in both species (Figs. 24, 38).

Description. Male. Dimensions: LB: 10.0. LR: 1.60. WR: 1.50. LP: 3.20. WP: 3.20. LE: 7.00. WE: 4.90. $\mathrm{N}=1$ for all measurements. Dorsal habitus as shown in Fig. 5.

Forehead with larger scaly spot. Lateral parts of rostrum covered with pale green narrow scales and golden long hairs before antennal scrobes. Pronotum with a pair of small lateral spots of general scales in middle. Each elytron with the following seven scaly markings: 1 ) small subbasal spot on interval III, 2) antimedian transverse band on entire width, 3) small postmedian spot on interval I, 4) long broad stripe extending from behind middle to just before apex of interval III, 5) postmedian elliptic patch on interval $\mathrm{V}, 6$ ) postmedian longitudinal patch on interval VII, and 7) long stripe extending from middle to apex along outer margin; marginal stripe become much thinner on apical half. Each femur sparsely covered with fine brown hairs near apex in addition to general vestiture. Tibial vestiture darker. Intercoxal part of mesosternum covered with general scales along midline. Eyes more strongly prominent. Rostrum with shallower dorsal concavity; sides slightly more strongly expanded in apical part, LR/WR 1.07. Antennal club slightly stouter. Pronotum more gradually convex on basal half, WP/LP 1.00. Elytra more strongly elongate apically, LE/WE 1.43, WE/WP 1.53, LE/LP 2.19. Legs much slenderer; hind tibiae more strongly incurved. Genitalia as illustrated (Figs. 38-41). Aedeagal body (Figs. 38, 39) subparallel-sided from basal $1 / 4$ to apical $1 / 5$, narrowly rounded at apex. Endophallic sclerites (Fig. 38) conjointly forming oblong-obcordate outline whose apical margin is moderately emarginate in middle. Otherwise, essentially as in P. hirokii.

Female. Unknown.

Type material. Holotype male (NIAES Type Specimen Code No. COL-276), "Mt. Syniop / Mindanao I. / Philippines / 22. IV. 1994" (typed on a white card), "KAORU SAKAI / COLLECTION" (typed on a white card), " $\widehat{O}$ " (typed on a white card); "[HOLOTYPE] Male / Pachyrhynchus naokii / Yoshitake, 2012 / Det. Hiraku Yoshitake, 2011" (typed on a red card).

Distribution. Philippines: Mindanao Island (Sultan Kudarat Province).

Etymology. The specific name is dedicated with my deepest love and gratitude to one of my twins, Naoki, who always makes me very happy with his pretty tearful face.

\section{Pachyrhynchus sphenomorphoides sp. nov.} (Figs. 6, 7, 31-37)

Diagnosis. Pachyrhynchus sphenomorphoides is similar in general appearance to P. atrocyaneus Schultze, 1922, which was described from Zamboanga Province, Mindanao Island. However, P. sphenomorphoides is readily distinguishable from $P$. atrocyaneus by the much strongly convex pronotum. Judging from similarities in the male and female genital structures, $P$. sphenomorphoides may have some relationship to the two previous species, P. hirokii and P. naokii.

Description. Male. Dimensions: LB: 8.30-9.30 (holotype 9.30; mean 8.93). LR: 1.25-1.45 (holotype 1.40; mean 1.37). WR: 1.25-1.45 (holotype 1.40; mean 1.37). LP: 3.10-3.50 (holotype 3.50; mean 3.33). WP: 2.85-3.30 (holotype 3.30; mean 3.15). LE: 5.35-6.10 (holotype 6.00; mean 5.82). WE: 3.65-4.40 (holotype 4.00; mean 4.02). $\mathrm{N}=3$ for all measurements. Dorsal habitus as shown in Fig. 6.

Integument glossy purplish black; head and pronotum often tinged with navy blue.

Lateral parts of rostrum covered with pale green hairlike scales and golden long hairs before antennal scrobes. Prothorax with the following four scaly markings: 1) 

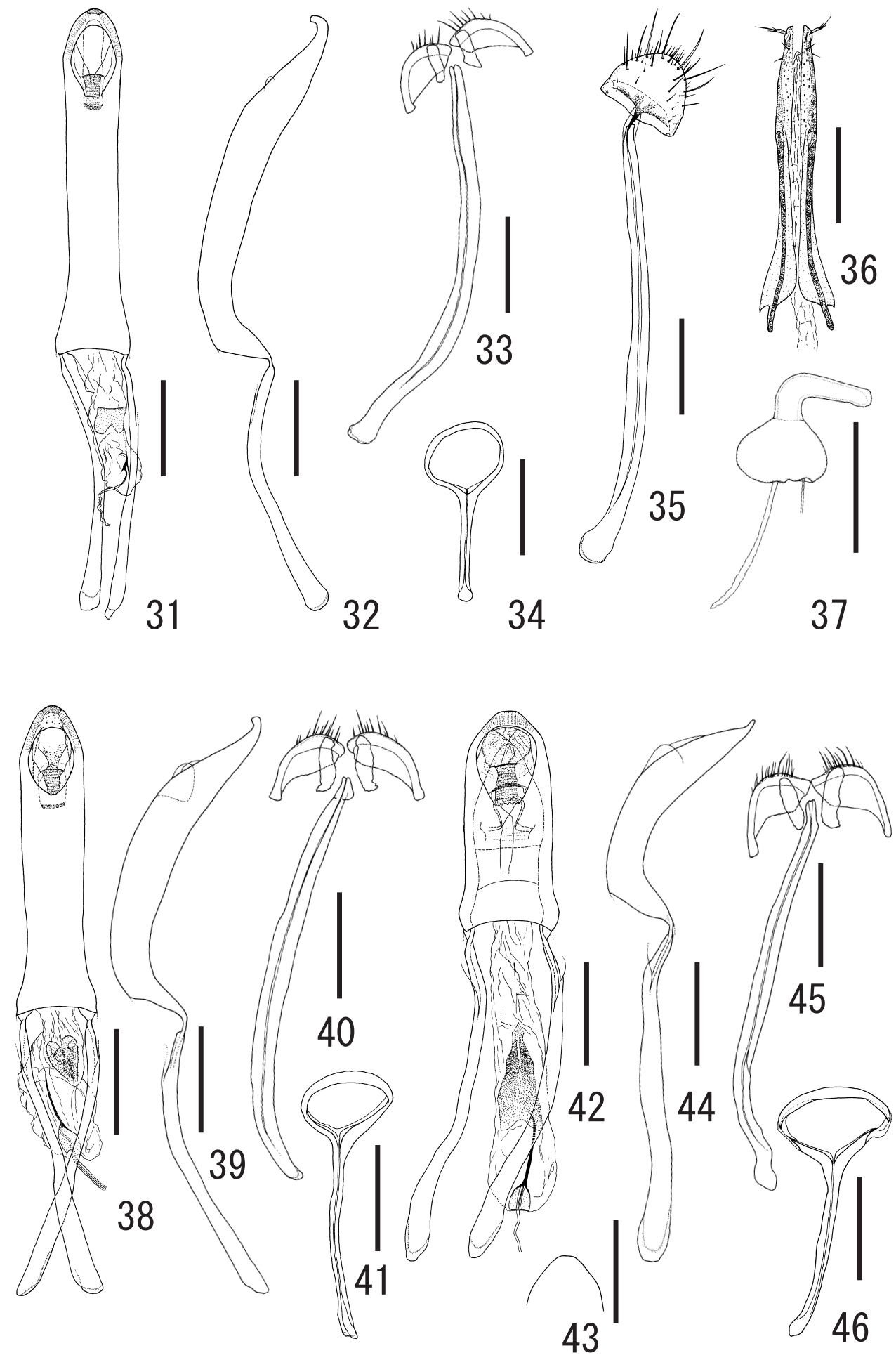

Figs. 31-46. Male and female genitalia of Pachyrhynchus spp. - 31-34, Pachyrhynchus sphenomorphoides sp. nov., holotype male; 35-37, ditto, paratype female; 38-41, P. naokii sp. nov., holotype male; 42-46, P. pseudamabilis sp. nov., holotype male. $31,38,42$, Aedeagus in dorsal view; 43, apex of aedeagal body in dorsal view; 32, 39, 44, aedeagus in lateral view; 33, 40, 45, sternite IX in dorsal view; $34,41,46$, tegmen in dorsal view; 35 , sternite VIII in ventral view; 36 , apex of ovipositor in dorsal view; 37 , spermatheca. Scale: $0.50 \mathrm{~mm}$. 
longitudinal patch of creamy white round scales in middle near base, 2) narrow lateroventral stripe of pale green round to elliptic scales on each side, 3) a pair of indistinct lateral patches along basal margin, and 4) a pair of transverse lateral patches of creamy white round scales along apical margin; both pairs of lateral patches very widely separated on pronotum, respectively. Each elytron with the following eleven scaly markings of white round scales: 1) antimedian spot on interval II, 2-4) subbasal, postmedian, and subapical spots on interval II, 5) antimedian spot on interval VI, 6, 7) antimedian and postmedian spots on interval VII, 8) subapical spot on interval IX, and 9-11) subbasal and apical spots and long median stripe on marginal part. Sterna and venter sparsely covered with fine light-colored hairs in addition to minute pubescence, with markings of glossy light-colored round scales; intercoxal parts of pro- and mesosterna covered with general scales; metasternum with a pair of small scaly patches on sides; scaly patches on ventrites I and II much smaller.

Antennal funicular segment II slightly stouter, less than twice as long as wide. Rostrum stouter, as long as wide, LR/WR 1.00; dorsal contour more strongly arched in and more strongly raised at basal half; ventral surface widely convex along midline on basal half. Prothorax slightly longer than wide, WP/LP $0.92-0.97$, dorsally very strongly convex, more strongly constricted near base. Elytra subobovate, narrower, LE/WE 1.39-1.50, WE/WP 1.21-1.33, slightly shorter, less than twice as long as prothorax, LE/LP 1.71-1.79, more weakly convex dorsally. Genitalia as illustrated (Figs. 31-34). Aedeagal body (Figs. 31, 32) slenderer, nearly 1.5 times as long as aedeagal apodemes, more strongly bent dorsally at apex; sides gently convergent apically in apical $1 / 6$, then shallowly rounded at apex. Endophallus (Fig. 31) with laminate sclerite whose basal margin is emarginate in middle. Tegminal apodeme shorter, slightly longer than diameter of tegminal ring (Fig. 34). Otherwise, essentially as $P$. hirokii.

Female. Dimensions: LB: 9.20-11.30 (mean 10.15). LR: $1.25-1.55$ (mean 1.43). WR: $1.30-1.55$ (mean 1.44). LP: $3.05-3.40$ (mean 3.31). WP: 2.80-3.60 (mean 3.18). LE: 6.40-7.70 (mean 6.90). WE: 4.55-5.50 (mean 4.95). $\mathrm{N}=5$ for all measurements. Dorsal habitus as shown in Fig. 7.

Rostrum LR/WR 0.96-1.00. Prothorax WP/LP 0.921.06. Elytra much wider, LE/WE 1.38-1.41, WE/WP 1.53-1.63, more strongly elongate apically, LE/LP 2.002.27. Venterites I and II slightly inflated. Ventrite V widely shallowly depressed along margins, with obtuse triangular laminate projection in middle of apex. Genitalia as illustrated (Figs. 35-37). Otherwise, essentially as in males.

Type material. Holotype male (NIAES Type Specimen Code No. COL-277), "[REP. OF THE PHILIPPINES] / Basilan Is., near Zamboanga / Peninsula of West Mindanao, / VII. 1990, native collector leg." (typed on a white card); "T. Kumazawa / Collection" (typed on a white card); "[HOLOTYPE] Male / Pachyrhynchus / sphenomorphoides / Yoshitake, 2012 / Det. Hiraku Yoshitake, 2011" (typed on a red card). Paratypes (9 exs.). PHILIPPINES: BASILAN ISLAND. 2 males and 7 females, same data as the holotype.

Distribution. Philippines: Basilan Island.

Etymology. This new species is named after its superficial resemblance to species belonging to Sphenomorpha, one of the 14 genera of the Pachyrhynchini.

\section{Pachyrhynchus pseudamabilis sp. nov.} (Figs. 9-12, 42-54)

Diagnosis. Pachyrhynchus pseudamabilis is similar in general appearance to P. amabilis Schultze, 1922, which was described from Lindaban, Bukidnon Province, Mindanao Island. However, P. pseudamabilis is readily distinguishable from $P$. amabilis by the following features: forehead narrower, at most slightly depressed in middle, not prominent along internal margins of eyes which are more strongly prominent from outline of head; outline of each eye highest behind middle; dorsal concavity of rostrum narrower; elytra strongly shiny, widest slightly before middle. This new species shows a remarkable intraspecific variation in the length and density of the pubescence on the body surface, the size and shape of the scaly patches on the elytra, and the shape of the apex of the aedeagal body.

Description. Male. Dimensions: LB: 9.40-11.95 (holotype 11.50; mean 10.97). LR: 1.60-2.00 (holotype 2.00; mean 1.86). WR: 1.55-1.95 (holotype 1.95; mean 1.78). LP: 3.30-3.95 (holotype 3.60; mean 3.56). WP: 3.35-4.10 (holotype 4.00; mean 3.81). LE: 6.50-8.05 (holotype 7.95; mean 7.52). WE: 4.70-5.85 (holotype 5.50; mean 5.29). $\mathrm{N}=5$ for all measurements. Dorsal habitus as shown in Figs. 9, 11.

Integument mostly dark glowing red, often with copper or dark-blue tinge; antennae black except scape; tarsi very dark bluish green. Body surface mostly strongly shiny, except underside with weaker luster.

Body with glossy pale green to dark yellow markings of round recumbent scales. Head moderately minutely pubescent, sometimes mostly glabrous; forehead with small scaly patch on middle of apex. Rostrum moderately pubescent, sometimes subglabrous, with elliptic scaly 

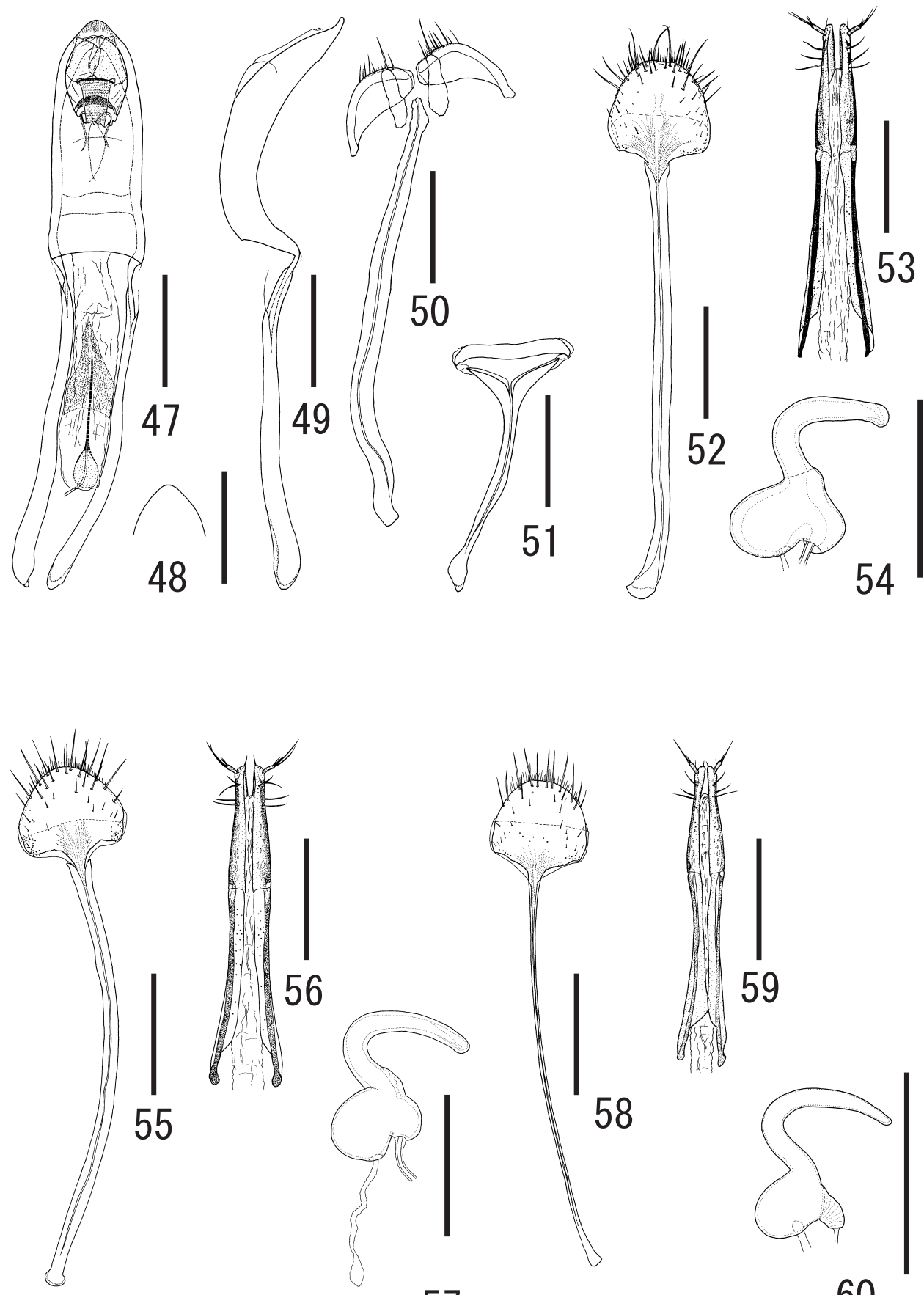

57

Figs. 47-60. Male and female genitalia of Pachyrhynchus spp. - 47-51, Pachyrhynchus pseudamabilis sp. nov., paratype male; 52-54, ditto, paratype female; 55-57, P. subamabilis sp. nov., holotype female; 58-60, P. zamboanganus sp. nov., holotype female. -47, Aedeagus in dorsal view; 48 , apex of aedeagal body in dorsal view; 49, aedeagus in lateral view; 50, sternite IX in ventral view; 51 , tegmen in ventral view; $52,55,58$, sternite VIII in ventral view; 53, 56, 59, apex of ovipositor in dorsal view; 54 , 57,60 , spermatheca. Scale: $0.50 \mathrm{~mm}$. 
patch on basal half along midline; scaly patch connected basally with that on forehead; lateroventral parts just behind antennal scrobes covered with dense elliptic to short hair-like scales which form oblique elliptic patch on each side of rostrum; lateroventral parts before antennal scrobes moderately covered with golden long hairs, mingled with linear to elliptic scales which form short median stripe on each side of rostrum. Prothorax mostly glabrous dorsally, with the following three scaly markings: 1) transverse band along subapical constriction, 2) broad lateroventral stripe on each side, and 3) transverse band along apical margin; each marking moderately clothed with short suberect pubescence; subbasal band sharply produced apically in middle; lateroventral stripe arched ventrally. Each elytron with two large scaly patches, one on basal half and another on apical half, usually moderately pubescent but sometimes subglabrous on non-squamose part; squamose parts rather densely clothed with fine erect hairs; basal patch obliquely depressed obovate, extending from interval II to external margin of elytron, gradually widened toward elytral margin; apical patch subtriangular, extending from interval II to external margin of elytron, with basal margin arched posteriorly. Coxae mostly sparsely covered with dark fine hairs; anterior parts of fore coxae densely covered with general scales, mingled with light-colored hairs. Femora sparsely minutely pubescent except apical parts with denser and longer pubescence. Fore femora rather densely covered with fine light-colored hairs and round to hair-like scales on basal and subapical parts along anterior margins; scales forming elliptic patch on subapical part on each leg. Mid and hind femora clothed with similar vestiture to that of fore femora along posterior margins. Tibiae fringed with long light-colored hairs along internal margins, sparsely mingled with dark stout hairs; fore tibiae moderately covered with long light-colored hairs on dorsal surfaces, sparsely covered with similar hairs on ventral surfaces, and moderately pubescent on external marginal parts except apices; hairs on ventral surfaces become longer apically; mid and hind tibiae sparsely covered with long light-colored hairs on dorsal surfaces, moderately covered with similar hairs on ventral surfaces, and moderately pubescent on external marginal parts except apices; hairs on dorsal surfaces become longer apically. Sterna sparsely clothed with fine subrecumbent light-colored hairs, with markings of general scales; prosternum mostly densely covered with scales; intercoxal part of mesosternum mostly densely covered with scales; metasternum entirely densely covered with scales. Venter moderately pubescent; ventrite I with a pair of large transverse scaly patches on sides along apical margin; ventrite II simple, lacking scaly markings; ventrite $\mathrm{V}$ fringed with long suberect hairs along lateral and apical margins.

Head moderately finely punctured; forehead flattish or slightly depressed on middle, nearly three times as wide as eye width; eyes relatively large, strongly prominent from outline of head; outline of each eye highest behind middle. Antennae with scape short and stout, slightly shorter than funicle, moderately clavate; funicular segment I less than twice as long as wide, nearly 1.5 times as long as II; segment II slightly longer than wide, nearly 1.5 times as long as III; segments III-V subequal in length, nearly as long as wide, nearly as long as but slightly narrower than VI; segment VI slightly wider than long, slightly shorter and narrower than VII; segment VII slightly shorter than wide; club subovoid, less than twice as long as wide. Rostrum barely longer than wide, LR/ WR 1.03-1.08; dorsum moderately finely punctured, with deep obtriangular concavity on basal half, weakly bulging on apical half; apical bulge dorsally flattish, with shallow indistinct sulcus along midline from apical half to $1 / 4$; dorsal contour of forehead and rostrum discontinuous; dorsal contour of rostrum weakly arched in basal half, then gradually raised at basal half, and finally gradually declined to apex; sides slightly widened apically; ventral surface simple, not convex along midline. Prothorax subspherical, nearly as long as or barely longer than wide, WP/LP 1.02-1.11; dorsum smooth, moderately finely punctured, weakly convex; dorsal contour highest at middle; sides gently dilated from moderately constricted base, widest at middle, then gently convergent apicad, and finally slightly constricted behind apex; basal and apical margins subtruncate; subbasal and subapical grooves entirely distinct. Elytra subobovoid, LE/WE 1.38-1.46, moderately wider than prothorax, WE/WP 1.35-1.43, nearly twice as long as prothorax, LE/LP 1.97-2.21, weakly striate-punctured, with intervals evenly flattish; dorsum moderately convex; dorsal contour highest at middle; sides weakly, gradually dilated from base, widest slightly before middle, then gently narrowed to weak subapical constrictions, and finally gently rounded at apices. Metasternum flat on disc. Ventrite I widely depressed on disc; apex of discal depression reaching apical margin of ventrite $\mathrm{I}$. Ventrite $\mathrm{V}$ widely truncate at apex. Legs slender; femora rather strongly clavate; tibiae weakly incurved apically, sharply minutely serrate along internal margins, mucronate at apices; tibial mucrones vestigial on hind legs. Genitalia as illustrated (Figs. 42-51). Spiculum gastrale (Figs. 45, 50) slender, nearly twice as long as aedeagal body, slightly longer than aedeagal apodemes, moderately curved leftward. Tegmen (Figs. 46, 51) with 
very slender apodeme which is nearly twice as long as diameter of tegminal ring. Aedeagal body (Figs. 42-44, 47-49) stout, in lateral view, more or less strongly curved ventrally, gradually attenuate apically from apical $1 / 3$, and slightly bent dorsally at apex; sides moderately or rather strongly narrowed from base to basal $1 / 5$, subparallel to basal $3 / 5$, then weakly, gradually narrowed to subapical part, and finally more or less strongly convergent to apex; apex of aedeagal body variable in shape from widely truncate (Fig. 43) to narrowly rounded (Fig. 48); aedeagal apodemes relatively long, nearly 1.5 times as long as aedeagal body. Endophallus (Figs. 42, 47) bearing short flagellum guide in basal part and subtriangular laminate sclerite in subbasal part.

Female. Dimensions: LB: 11.0-12.6 (mean 11.84). LR: 1.75-2.05 (mean 1.95). WR: 1.70-1.95 (mean 1.81). LP: 3.30-3.65 (mean 3.43). WP: 3.60-3.95 (mean 3.77). LE: 7.60-9.00 (mean 8.45). WE: 5.60-6.50 (mean 6.13). $\mathrm{N}=5$ for all measurements. Dorsal habitus as shown in Figs. 10, 12.

Rostrum LR/WR 1.03-1.21. Prothorax WP/LP 1.071.13. Elytra more strongly convex dorsally, LE/WE 1.361.40, much wider than prothorax, WE/WP 1.56-1.68, with stronger subapical constrictions, elongate apically, LE/LP 2.30-2.52, and more acutely rounded at apices. Venterite I flattish or slightly inflated on disc. Ventrite $\mathrm{V}$ very widely depressed along lateral margins. Genitalia as illustrated (Figs. 52-54). Otherwise, essentially as in males.

Type material. Holotype male (NIAES Type Specimen Code No. COL-278), “[REP. OF THE PHILIPPINES] / Mindanao I., Mt. Apo / XI. 2008, native collector" (typed on a white card); "HIRAKU YOSHITAKE / COLLECTION" (typed on a white card); "[HOLOTYPE] Male / Pachyrhynchus pseudamabilis / Yoshitake, 2012 / Det. Hiraku Yoshitake, 2011" (typed on a red card). Paratypes (59 exs.). PHILIPPINES: MINDANAO ISLAND. Mt. Apo: 1 male, i. 1978, T. Fujisawa leg. (Specimen No. 24-0474310, NIAES); 1 female, vi. 1985, native collector leg. (Specimen No. 24-0474311, NIAES); 2 females, xi. 2008, native collector leg. (Specimen Nos. 24-0474312, 24-0474313, NIAES); 4 females, iv. 2010, native collector leg. (Specimen Nos. 24-0474314 240474317); 2 males and 4 females, v. 2010, native collector leg. (Specimen Nos. 24-0474318 24-0474323, NIAES); 10 males and 15 females, vi. 2010, native collector leg. (Specimen Nos. 24-0474324 24-0474348, NIAES); 5 males and 10 females, ix. 2010, native collector leg. (Specimen Nos. 24-0474349 24-0474363, NIAES); 2 females, x. 2010, native collector leg. (Specimen Nos. 24-0474364, 24-0474365, NIAES). Mt. Apo, North
Cotabato Province: 2 males, xii. 2010, native collector leg. (Specimen Nos. 24-0474366, 24-0474367, NIAES); 1 female (Specimen No. 24-0474368, NIAES; with no further data).

Distribution. Philippines: Mindanao Island (Mt. Apo). Etymology. This species is named after its close similarity to $P$. amabilis in general appearance.

Pachyrhynchus subamabilis sp. nov. (Figs. 8, 55-57)

Diagnosis. Pachyrhynchus subamabilis closely resembles $P$. amabilis in general appearance, but $P$. subamabilis clearly differs from $P$. amabilis by the dark glowing red elytra which are immaculate and indistinctly striate-punctured. Judging from similarities in the general appearance and female genital structures, $P$. subamabilis may also be related to $P$. pseudamabilis.

Description. Female. Dimensions: LB: 12.4. LR: 2.00. WR: 1.85. LP: 3.80. WP: 3.90. LE: 8.70. WE: 6.45. $\mathrm{N}=1$ for all measurements. Dorsal habitus as shown in Fig. 8.

Integument dark glowing red, with bluish green sheen; antennae and tarsi very dark bluish green. Body mostly subopaque except elytra opaque and legs moderately shiny. Forehead, rostrum, and elytra immaculate; dorsal concavity of rostrum furnished with several round recumbent scales. Eyes more strongly prominent. Rostrum LR/ WR 1.08. Prothorax more weakly convex dorsally, with sides gradually dilated apically from weaker subapical constrictions, widest at apical 1/3, WP/LP 1.03. Elytra more weakly convex dorsally, indistinctly striate-punctured, LE/WE 1.35, WE/WP 1.65, LE/LP 2.29; sides gradually dilated apically to before middle. Legs slenderer. Genitalia as illustrated (Figs. 55-57). Otherwise, essentially as in P. pseudamabilis.

Male. Unknown.

Type material. Holotype female (NIAES Type Specimen Code No. COL-279), "Mt. Apo / S. Mindanao / Philippines / 28. III. 1994" (typed on a white card), "KAORU SAKAI / COLLECTION" (typed on a white

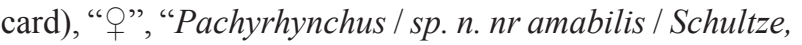
1922 / Det. Hiraku Yoshitake, 2010” (partially hand-written on a yellow card), "[HOLOTYPE] Female / Pachyrhynchus subamabilis / Yoshitake, 2012 / Det. Hiraku Yoshitake, 2011" (typed on a red card).

Distribution. Philippines: Mindanao Island (Mt. Apo).

Etymology. The specific name is formed by a combination of the Latin prefix sub- meaning "almost" and the name of the allied species, denoting its close similarity to $P$. amabilis in general appearance. 
Pachyrhynchus zamboanganus sp. nov.

(Figs. 13, 58-60)

Diagnosis. Pachyrhynchus zamboanganus resembles P. basilanus Heller, 1923 from Basilan Island in general appearance, but $P$. zamboanganus is unable to be confused with $P$. basilanus by the following points: prothorax wider, with two transverse scaly bands on entire width, one along basal and another along apical margins; elytra more strongly convex dorsally; dorsal contour of each elytron highest at middle and more rapidly declined apically in apical half; sides of elytra more weakly dilated in basal half, widest at middle, then more acutely narrowed to subapical constrictions, and finally terminated in rounded apices. This new species may have some relation to $P$. pseudamabilis and $P$. subamabilis, which are described in this paper from Mindanao Island, in view of the similarity in genital structures between them.

Description. Female. Dimensions: LB: 9.85. LR: 1.60. WR: 1.45. LP: 3.20. WP: 3.40. LE: 6.60. WE: 4.80. $\mathrm{N}=1$ for all measurements. Dorsal habitus as shown in Fig. 13.

Integument dark bluish black except antennae and tarsi black. Body with sparser vestiture and dull orange scaly markings; forehead and dorsum of rostrum subglabrous, not squamate; each side of rostrum only covered with dark hairs on lateroventral part before antennal scrobe, not squamate; elytra with transverse oblique scaly band which extends from suture to lateral margin; band sharply narrowed from suture to stria I, and then gradually widened laterally. Eyes more weakly prominent. Antennal club more acute at apex. Rostrum LR/WR 1.10, flattish on basal half. Prothorax wider, WP/LP 1.06, more strongly convex dorsally. Elytra LE/WE 1.38, WE/WP 1.41, LE/LP 2.06; dorsal contour more gradually raised apically in basal half, highest at middle, and then more rapidly declined to apex; sides more gradually dilated in basal half, widest at middle, and more acutely narrowed to subapical constrictions. Fore tibiae simple, not bisinuate. Genitalia as illustrated (Figs. 58-60). Otherwise, essentially as in P. pseudamabilis.

Male. Unknown.

Type material. Holotype female (NIAES Type Specimen Code No. COL-280), “[REP. OF THE PHILIPPINES] / West Mindanao, Zamboanga / del Norte Province, III. 2010" (typed on a white card), "HIRAKU YOSHITAKE / COLLECTION" (typed on a white card), "O" (typed on a white card), "[HOLOTYPE] Female / Pachyrhynchus / zamboanganus / Yoshitake, 2012 / Det. Hiraku Yoshitake, 2011" (typed on a red card).

Distribution. Philippines: Mindanao Island (Zamboanga del Norte Province).
Etymology. This species is named after its type locality, Zamboanga.

\section{Pachyrhynchus caeruleovittatus sp. nov.}

(Figs. 14, 15, 61-67)

Diagnosis. Pachyrhynchyus caeruleovittatus is distinctive enough not to be confused with any other congeners by the black body and the very wide elytra with evenly convex intervals except interval III and lateral two intervals, each of which is concealed by glossy pale blue stripes of recumbent round scales. This new species may have some relation to $P$. hirokii and its relatives from the Mindanao Islands in view of the similarity in genital structures between them.

Description. Male. Dimensions: LB: 10.4-10.9 (holotype 10.40; mean 10.7). LR: 1.70-1.90 (holotype 1.70; mean 1.80). WR: 1.55-1.75 (holotype 1.55; mean 1.65). LP: 3.20-3.35 (holotype 3.20; mean 3.28). WP: 3.05-3.35 (holotype 3.05; mean 3.20). LE: 7.30-7.95 (holotype 7.30; mean 7.63). WE: 4.60-5.05 (holotype 4.60; mean 4.88). $\mathrm{N}=3$ for all measurements. Dorsal habitus as shown in Fig. 14.

Integument black except elytra castaneous apically. Body surface mostly strongly shiny.

Body mostly subglabrous, with glossy pale blue markings of recumbent round scales. Head glabrous. Rostrum sparsely minutely pubescent, with narrow elliptic scaly patch on basal half along midline; lateroventral parts densely covered with dense general scales and sparse short hairs and hair-like scales behind antennal scrobes, moderately covered with pale blue hair-like scales and darker fine hairs before antennal scrobes, furnished with long golden hairs near apex. Prothorax glabrous except the following seven scaly markings: $1-3$ ) a trio of small elliptic patches on subbasal parts, 4, 5) a pair of small transverse elliptic patches along apical margin, and 6, 7) a pair of broad lateroventral stripes above fore coxae. Each elytron sparsely covered with minute pubescence which becomes longer near apex, with two broad scaly stripes, one extending from behind base to before apex of interval III and another extending from just behind base to apical $1 / 4$ of intervals IX and X; interval I sometimes with small scaly spot on apical $1 / 5$; interval V sometimes with small scaly spot on basal 1/5 and/or narrow elliptic patch on postmedian part. Fore coxae sparsely covered fine dark hairs. Fore femora mostly covered with sparse minute pubescence which becomes longer apically, rather densely covered with dark short hairs and pale blue hair-like scales on basal and subbasal parts along anterior margins. Mid and hind femora covered with sparse minute pubescence 

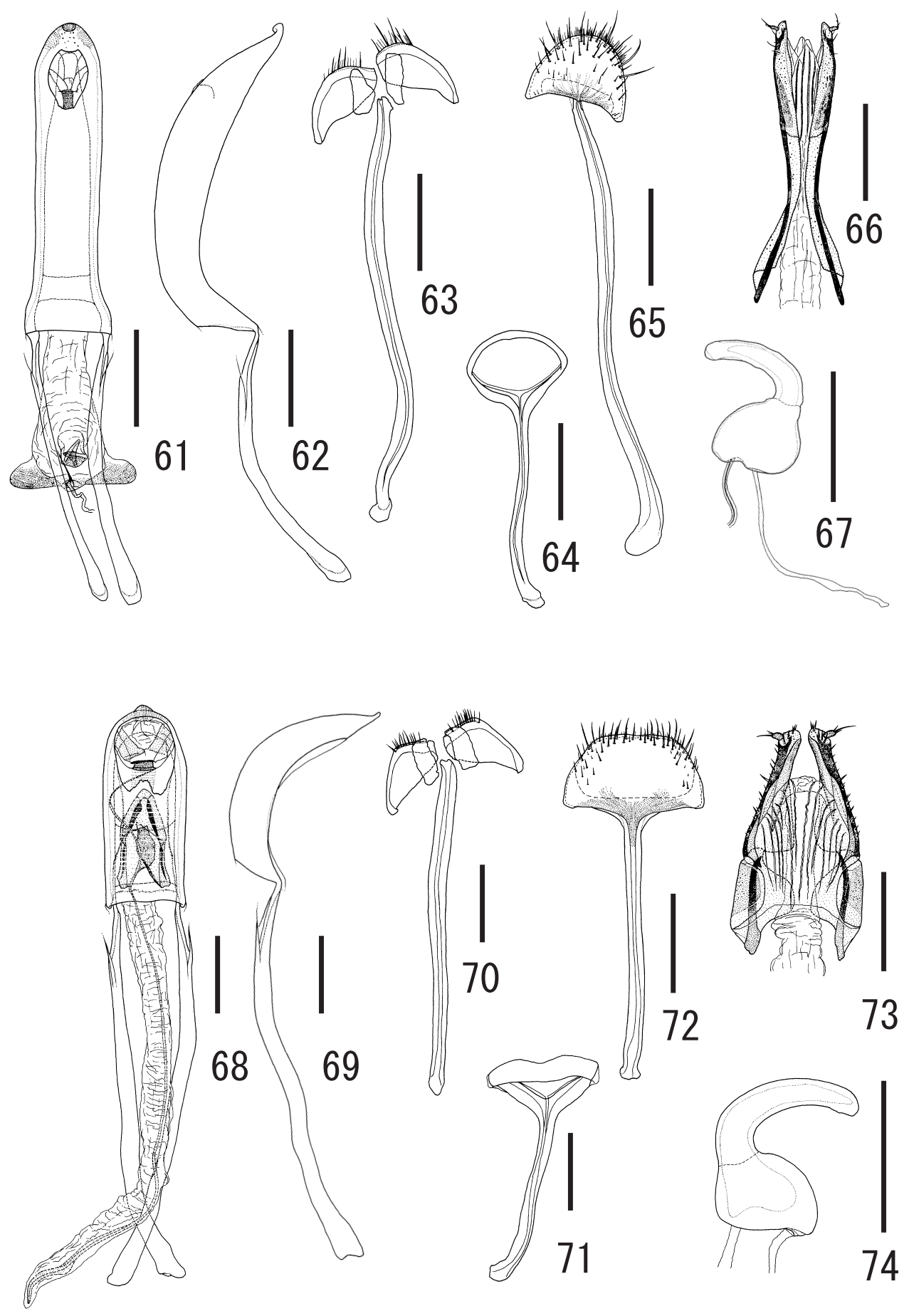

Figs. 61-74. Male and female genitalia of Pachyrhynchus spp. - 61-64, Pachyrhynchus caeruleovittatus sp. nov., holotype male; 65-67, ditto, paratype female; 68-71, P. apoensis, holotype male; 72-83, ditto, paratype female. 61, 68, Aedeagus in dorsal view; 62, 69, aedeagus in lateral view; 63, 70, sternite IX in ventral view; 64, 71, tegmen in ventral view; 65, 72, sternite VIII in ventral view; 66, 73, apex of ovipositor in dorsal view; 67,74 , spermatheca. Scale: $0.50 \mathrm{~mm}$. 
which becomes longer apically, rather densely covered with dark short hairs and pale blue hair-like scales on basal and subbasal parts along posterior margins. Tibiae sparsely minutely pubescent; each tibia fringed with long golden hairs along internal margin, sparsely mingled with dark stout hairs; vestiture become longer apically. Intercoxal part of prosternum partially densely covered with general scales. Intercoxal part of mesosternum mostly densely covered with general scales. Metasternum with a pair of small ovate patches on sides. Venter sparsely minutely pubescent; ventrite I with a pair of large scaly patches on sides along apical margin, with longer vestiture on disc; ventrite II with a pair of small scaly patches on sides along apical margin, with longer vestiture on apical half; ventrites III and IV with long hairs along apical margins; ventrite $\mathrm{V}$ covered with longer suberect hairs along margins.

Head faintly minutely punctured; forehead flattish, nearly three times as wide as eye width; eyes relatively large, strongly convex from outline of head. Antennae with scape stout, nearly as long as funicle, moderately clavate; funicle relatively stout; funicular segment I nearly twice as long as wide, slightly longer than II; segment II nearly 1.5 times as long as wide, 1.7 times as long as III; segments III-VI subequal in length, nearly as long as wide, slightly shorter and narrower than VII; segment VII slightly wider than long; club subellipsoidal, less than twice as long as wide, as long as funicular segments IV to VII combined. Rostrum slightly longer than wide, LR/ WR 1.03-1.15; dorsum moderately minutely punctured, with shallow obovate concavity on basal half, moderately bulging on apical half; apical bulge flattish dorsally; dorsal contour of forehead and rostrum slightly discontinuous; dorsal contour of rostrum weakly arched in basal half, then moderately raised at basal half, and finally gradually declined to apex; sides moderately widened apically; ventral surface simple, not convex along midline. Prothorax subspherical, nearly as long as wide, WP/LP $0.95-1.00$; dorsum faintly minutely punctured, slightly depressed on concealed parts by scaly markings, weakly convex on disc; dorsal contour highest at apical $1 / 4$; sides strongly dilated from strongly constricted base to basal $1 / 3$, subparallel to basal $2 / 3$, then gradually convergent apicad, and faintly widely constricted before apex; basal and apical margins subtruncate; subbasal groove entirely distinct; subapical groove obscure. Elytra broadly subellipsoidal, LE/WE 1.53-1.59, much wider than prothorax, WE/WP 1.51-1.56, more than twice as long as prothorax, LE/LP 2.28-2.37, deeply striate-punctured, with evenly convex intervals except III, IX, and X slightly depressed on squamose parts; dorsum moderately convex; dorsal contour highest before middle; sides gradually dilated from base, widest before middle, then strongly narrowed to strong subapical constriction, and finally widely rounded at apices. Metasternum and ventrite I widely conjointly depressed on disc, forming large circular depression; apex of discal depression reaching apical margin of ventrite I. Ventrite $\mathrm{V}$ widely subtruncate at apex. Legs very slender; femora strongly clavate; tibiae sparsely acutely serrate along internal margins, weakly incurved apically, mucronate at apices; tibial mucrones vestigial on hind legs. Genitalia as illustrated (Figs. 61-64). Spiculum gastrale (Fig. 63) slender, slightly longer than aedeagal body, bisinuate in dorsal view. Tegmen (Fig. 64) with very slender apodeme which is nearly twice as long as diameter of tegminal ring. Aedeagal body (Figs. 61, 62) slender, in lateral view, rather strongly curved ventrally near base, rapidly attenuate apically from subapical part, and bent dorsally at apex; sides rather strongly narrowed from base to basal $1 / 6$, then subparallel to subapical part, and finally rather strongly convergent to round apex; aedeagal apodemes slightly shorter than aedeagal body. Endophallus (Fig. 61) with short flagellum guide, a pair of spiculate fields, and a pair of subtriangular laminate sclerites in basal part.

Female. Dimensions: LB: 11.7-12.6 (mean 11.94). LR: 1.70-2.15 (1.87). WR: 1.60-1.70 (1.63). LP: 3.203.55 (3.32). WP: 3.20-3.40 (3.30). LE: 8.50-9.20 (8.67). WE: $5.75-6.40(6.04) . \mathrm{N}=5$ for all measurements. Dorsal habitus as shown in Fig. 15.

Rostrum LR/WR 1.06-1.26. Prothorax WP/LP 0.961.03. Elytra more strongly convex dorsally, wider, LE/ WE 1.41-1.48, much wider than prothorax, WE/WP 1.74-1.88, more strongly elongate apically, LE/LP 2.542.69 , and more acutely rounded at apices. Metasternum simple, not depressed on disc. Venterite I slightly inflated. Ventrite V widely shallowly depressed along margins, with obtuse subtriangular laminate projection in middle of apex. Genitalia as illustrated (Figs. 65-67). Otherwise, essentially as in males.

Type material. Holotype male (NIAES Type Specimen Code No. COL-281), "Mt. Parker / Mindanao Is. / Philippines / VIII. 2006" (typed on a white card), "KAORU SAKAI / COLLECTION" (typed on a white card), "Pachyrhynchus / sp. n. ô / Det. Hiraku Yoshitake, 2010" (partially hand-written on a yellow card), "[HOLOTYPE] Male / Pachyrhynchus / caeruleovittatus / Yoshitake, 2012 / Det. Hiraku Yoshitake, 2011" (typed on a red card). Paratypes (7 exs.). PHILIPPINES: MINDANAO ISLAND. Mt. Parker, South Cotabato: 1 male and 2 females, 2004, native collector leg. (Specimen Nos. 24-0474369 24-0474371, NIAES; with no further 
data); 1 male and 2 females, iv. 2004, D. Mohagan leg. (Specimen Nos. 24-0474372 24-0474374, NIAES); 1 female, iv. 2006, native collector leg. (Specimen No. 24-0474298, NIAES).

Distribution. Philippines: Mindanao Island (South Cotabato Province).

Etymology. This species is named after the elytra with remarkable stripes of pale blue scales.

Pachyrhynchus apoensis sp. nov.

(Figs. 16, 68-74)

Pachyrrhynchus sp.: Sakaguti, 1979, 90, pl. 23, fig. 8 (Japanese name: Oo-akagane-katazou; Mt. Apo, Mindanao).

Diagnosis. Pachyrhynchus apoensis is similar in general appearance to P. corpulentus Schultze, 1922, which was described from Bukidnon Province, Mindanao Island. In addition to the unique scaly markings, however, $P$. apoensis differs from $P$. corpulentus by the narrower forehead, slightly prominent eyes from the outline of head, and slenderer antennal funicular segment II.

Description. Male. Dimensions: LB: 10.5-14.2 (holotype 11.70; mean 12.24). LR: 1.60-2.20 (holotype 1.75; mean 1.85). WR: 1.70-2.30 (holotype 1.85; mean 1.98). LP: $3.40-4.60$ (holotype 3.80; mean 4.00). WP: 3.40-4.60 (holotype 3.70; mean 3.95). LE: 7.40-9.50 (holotype 7.90; mean 8.43). WE: 5.30-6.80 (holotype 5.60; mean 5.92). $\mathrm{N}=5$ for all measurements. Dorsal habitus as shown in Fig. 16.

Integument dark glowing red, with green tinge; antennae reddish black except black scapes. Body surface mostly strongly shiny except underside with weaker luster.

Body mostly subglabrous, sparsely minutely pubescent, with glossy pale green markings of recumbent round scales. Head sparsely minutely pubescent; forehead between eyes with small circular scaly patch on median part. Each side of rostrum with larger oblong patch of elliptic to hair-like scales on lateroventral part behind antennal scrobe and with small circular scaly patch before it, furnished with long dark hairs near apex. Prothorax with a pair of small circular scaly patches on both sides of middle of pronotum; each side with short broad scaly stripe on lateroventral part above fore coxa. Each elytron with the following four scaly markings: 1) small elliptic postmedian patch along suture, 2) small elliptic subapical patch along suture, 3) very large basal patch which is narrowly deeply emarginate in middle of internal margin, and 4) large apical patch which widely shallowly emarginate in middle of internal margin; basal and apical patches usually connected along lateral margin by broad oblique scaly stripe, but sometimes divided into two to three smaller patches, respectively. Fore femora rather densely covered with short hairs and lanceolate to hair-like scales on basal and subapical parts along anterior margins. Mid and hind femora along posterior margins with vestiture as that on fore pair. Each tibia fringed with long hairs along internal margin, sparsely mingled with stout hairs. Each mesepimeron with small oblique-elliptic scaly patch along apical margin. Metasternum densely covered with general scales on sides. Ventrite I with a pair of small scaly patches on sides along apical margin; ventrite II with a pair of larger scaly patches on sides along apical margin; scaly patches on ventrite II more widely separated than those on ventrite $\mathrm{I}$; ventrite $\mathrm{V}$ moderately covered with fine dark hairs on apical 1/3.

Body moderately minutely punctured. Forehead slightly depressed in middle, nearly 2.5 times as wide as eye width. Eyes weakly convex from outline of head. Antennae with scape short and stout, slightly shorter than funicle, rather strongly clavate; funicle relatively stout; funicular segment I nearly 1.5 times as long as wide, slightly shorter than II; segment II nearly 1.7 times as long as wide, nearly twice as long as III; segments III-V subequal in length and width, nearly 1.3 times as wide as long, slightly shorter and narrower than VI; segment VI slightly wider than long, slightly shorter and narrower than VII; segment VII slightly wider than long; club subellipsoidal, nearly twice as long as wide, slightly longer than funicular segments V to VII combined. Rostrum barely shorter than wide, LR/WR 0.90-0.96; dorsum with obscure sulcus on basal half along midline, moderately bulging on apical half; apical bulge flattish dorsally, not sulcate medially; dorsal contour of forehead and rostrum slightly discontinuous; dorsal contour of rostrum weakly arched in basal half, then abruptly raised at basal half, and finally gradually declined to apex; sides rather strongly widened apically; ventral surface simple, not convex along midline. Prothorax subspherical, nearly as long as wide, WP/LP 0.97-1.00, weakly convex dorsally; sides strongly straightly dilated from very strongly constricted base, widest just before middle, then gently convergent apicad, and finally faintly constricted just behind apex; basal margin widely shallowly emarginate in middle; apical margin faintly bisinuate; subbasal groove entirely distinct; subapical groove become obscure dorsally; dorsal contour highest at middle. Elytra subellipsoidal, LE/WE 1.40-1.47, wider than prothorax, WE/WP 1.411.56 , slightly more than twice as long as prothorax, LE/LP 2.07-2.20, very smooth, not striate-punctured; dorsum 
strongly convex; dorsal contour highest slightly before middle; sides gently dilated from base to basal $1 / 3$, widest before middle, then gently narrowed to faint subapical constrictions, and finally more strongly convergent to narrowly rounded apices. Legs slender; femora moderately clavate; tibiae sparsely acutely serrate along internal margins, emarginate slightly behind apices along external margins, strongly incurved apically, and acutely mucronate at apices; tibial mucrones well-developed on all legs. Metasternum simple, not depressed on disc. Ventrite I shallowly depressed on disc; apex of discal depression not reaching apical margin of ventrite $\mathrm{I}$. Ventrite $\mathrm{V}$ widely rounded at apex, widely shallowly depressed along lateral margins. Genitalia as illustrated (Figs. 68-71). Spiculum gastrale (Fig. 70) slender, slightly longer than aedeagal body, substraight in dorsal view. Tegmen (Fig. 71) with slender apodeme which is nearly 1.6 times as long as diameter of tegminal ring. Aedeagal body (Figs. 68, 69) stout, strongly curved ventrally, with subtriangular median projection at apex; sides subparallel in basal 2/3 and then strongly convergent toward apex; aedeagal apodemes very slender, nearly twice as long as aedeagal body. Endophallus (Fig. 68) with extremely long flagellum guide, which extends from base to apex, and with a complex of some laminate sclerites in subapical part; laminate sclerites concealed by aedeagal body.

Female. Dimensions: LB: 11.50-13.00 (mean 12.31). LR: $1.70-1.85$ (mean 1.79). WR: $1.80-2.05$ (mean 1.93). LP: 3.40-3.65 (mean 3.55). WP: 3.45-3.80 (mean 3.66). LE: 8.30-9.40 (mean 8.86). WE: 5.95-6.60 (mean 6.36). $\mathrm{N}=5$ for all measurements.

Rostrum LR/WR 0.87-0.97. Prothorax with sides more weakly dilated, WP/LP 1.00-1.06. Elytra wider, LE/ WE 1.34-1.42, much wider and longer than prothorax, WE/WP 1.72-1.76, LE/LP 2.44-2.58. Venterite I slightly inflated. Genitalia as illustrated (Figs. 72-74). Otherwise, essentially as in males.

Type material. Holotype male (NIAES Type Specimen Code No. COL-282), "[REP. OF THE PHILIPPINES] / Mindanao I., Mt. Apo / IV. 2010, native collector leg." (typed on a white card), "HIRAKU YOSHITAKE / COLLECTION" (typed on a white card), " $\widehat{O}$ " (typed on a white card), "[HOLOTYPE] Male / Pachyrhynchus apoensis / Yoshitake, 2012 / Det. Hiraku Yoshitake, 2011" (typed on a red card). Paratypes (98 exs.). PHILIPPINES: MINDANAO ISLAND. Mt. Apo: 13 males and 13 females, i. 1978, T. Fujisawa leg. (Specimen Nos. 24-0474375 24-0474400, NIAES); 1 male, 3. i. 1978, T. Fujisawa leg. (Specimen No. 24-0474401, NIAES); 2 males, vi. 1985, native collector leg. (Specimen Nos. 24-0474402, 24-0474403, NIAES); 1 female, vi.
1986, native collector leg. (Specimen No. 24-0474404, NIAES); 2 males and 1 female, v. 1987, native collector (PCKS); 4 males and 2 females, 5. v. 1987, native collector (PCKS); 1 female, vi. 1987, native collector leg. (Specimen No. 24-0474405, NIAES); 1 female, vi. 1988, native collector leg. (Specimen No. 24-0474406, NIAES); 1 female, vii. 1986, native collector leg. (Specimen No. 24-0474407, NIAES); 4 males and 6 females, vi. 2004, native collector (PCKS); 1 male and 1 female, v. 2005, native collector (PCKS); 18 males and 7 females, xi. 2008, native collector leg. (Specimen Nos. 24-0474408 24-0474432, NIAES); 1 male and 3 females, same data as the holotype (Specimen Nos. 24-0474433 240474436, NIAES); 1 male, iii. 2009, native collector (PCKS); 10 males and 6 females, iv. 2009, native collector leg. (Specimen Nos. 24-04744441 24-0474456, NIAES); 1 male and 5 females, vi. 2010, native collector (Specimen Nos. 24-0474457 24-0474462, NIAES); 1 male and 1 female, ix. 2010, native collector leg. (Specimen Nos. 24-0474437, 24-0474438, NIAES); 1 male and 4 females, (Specimen Nos. 24-0474468 240474472, NIAES; with no further data). Mt. Apo, North Cotabato Province: 2 males, iv. 2004, native collector leg. (PCKS); 2 males, iv. 2004, D. Mohagan leg. (PCKS); 1 female, iv. 2006, native collector leg. (PCKS); 1 male, vi. 2006, native collector leg. (PCKS); 2 males and 2 females, ii. 2008, native collector leg. (PCKS); 2 males, viii. 2009, native collector leg. (PCKS); 2 males, ix. 2011, native collector leg. (Specimen Nos. 24-0474439, 24-0474440, NIAES); 1 male and 4 females (Specimen Nos. 24-0474463 24-0474467, NIAES).

Distribution. Philippines: Mindanao Island (Mt. Apo). Etymology. This species is named after its type locality, Mt. Apo.

\section{Acknowledgements}

I would like to express my sincere appreciation to Prof. Osamu Tadauchi (Kyushu University) for his guidance and encouragement during my doctoral and postdoctoral studies. I thank Kaoru Sakai (Tokyo), Tsutomu Takano (Tsukuba), and Yoshinobu Uémura (Tsukuba) for their kind offer of invaluable specimens and Prof. Emeritus Katsura Morimoto (Kyushu University) for his constant guidance. My thanks are also due to KlausDieter Klass, Olaf Jäger, Christian Schmidt, and Matthias Nuss (MTD) for their support during my visit to MTD in 2010. I acknowledge the assistance of Naoko Nakahara (Tsukuba) and Eri Tanaka (NIAES) in the course of this study. 


\section{H. YOSHITAKE}

\section{References}

Alonso-Zarazaga, M. A. \& C. H. C. Lyal, 1999. A World Catalogue of Families and Genera of Curculionoidea (Insecta: Coleoptera). (Excepting Scolytidae and Platypodidae). Entomopraxis, Barcelona.

Dalla Torre, K. W., M. van Emden \& F. van Emden, 1931. Curculionidae: Brachyderinae: Pachyrrhynchini. In: Schenkling, S. (ed.), Coleopterorum Catalogus, (119): 1-44. W. Junk, Berlin.

Germar, E. F., 1824. Insectorum species novae aut minus cognitae, descriptionibus illustratae. Vol. 1. Coleoptera. J. C. Hendelii et filii, Halae.

Heller, K. M., 1923. Neue malayische, meist philippinische Bockkäfer und ein neuer Rüsselkäfer. Tijds. voor Entomol., 66: $33-48,1 \mathrm{pl}$

Kuschel, G., 2008. Curculionoidea (weevils) of New Caledonia and Vanuatu: ancestral families and some Curculionidae. In: Grandcolas, P. (ed.), Zoologia Neocaledonica 6. Biodiversity studies in New Caledonia. Mém. Mus. Natn. Hist. Nat., 197: 99-250.

Marshall, G. A. K. 1952. Taxonomic notes on Curculionidae
(Col.). Annals and Mag. Nat. Hist., (12) 5: 261-270.

Sakaguti, K. 1979. Insects of the World 1. Southeast Asia I. Including Australia. Hoikusha Publishing Co., Osaka. (In Japanese, with English book title).

Schultze, W., 1922. Neunter Beitrag zur Coleopteren-Fauna der Philippinen. Deutsche Entomol. Zeit., 1922: 36-45 + 1 pl.

Schultze, W., 1923. A monograph of the Pachyrrhynchid group of the Brachyderinae, Curculionidae: Part I. Philipp. J. Sci., 23: $609-673+6$ pls.

Schultze, W., 1934. Thirteenth contribution to the Coleoptera fauna of the Philippines. Philipp. J. Sci., 53: 311-337+ 2 pls.

Schultze, W., 1937. Bemerkungen über Pachyrrhynchen von Kotosho - (Botel Tobago) und benachbarten Inseln. Mitt. Deutschen Entomol. Gesell., 8: 25-28.

Waterhouse, G. R., 1843. Descriptions of the species of the curculionideous genus Pachyrhynchus, Sch., collected by $\mathrm{H}$ Cuming, Esq., in the Philippine Islands. Trans. Roy. Entomol. Soc. Lond., 3: 310-327. [Read 1-III-1841].

Yoshitake, H., 2011. A new species of the subgenus Artapocyrtus of the genus Metapocyrtus (Coleoptera: Curculionidae: Entiminae) from Mindanao, the Philippines. Esakia, (50): 115-119. 